Chapter 23

\title{
Corrosion of Metals in Wood Products
}

\author{
Samuel L. Zelinka \\ Additional information is available at the end of the chapter \\ http://dx.doi.org/10.5772/57296
}

\section{Introduction}

The corrosion of metals in contact with wood has been studied for over 80 years, and in most situations wood is not corrosive [1]. Recently, however, the durability of fasteners in preservative-treated wood has become a concern. Changes in legislation and certification in the United States, the European Union, and Australasia have restricted the use of chromated copper arsenate (CCA), which was previously the most extensively used waterborne wood preservative $[2,3]$. Following these changes, several different wood preservatives have come to the market, some of which are much more corrosive than CCA [4-7]. Although a lot of recent research has been conducted in this area, no attempt has been made to summarize all the recent advances, and confusion exists about the corrosiveness of alternatives to CCA and proper materials selection for use in treated wood. In this chapter, we summarize information on why metals corrode in wood, how fast this corrosion occurs, and techniques to minimize corrosion in wood products.

\section{Wood as an electrolyte}

Understanding the microstructure and chemistry of wood is helpful in understanding how and why metals corrode in wood. Wood is an anisotropic, cellular material; long, hollow, narrow cells are orientated along the root-to-crown direction of the living tree. The types of cells and the structure of the wood material depend on if the tree was a hardwood (angiosperm, deciduous leaves) or softwood (gymnosperm, evergreen). Many of the structural differences between hardwoods and softwoods are highlighted in Figure 1 [8].

Despite the diversity in wood microstructure across genera and species, the cell wall of all wood species is composed of the same three structural polymers: cellulose, hemicelluloses, 


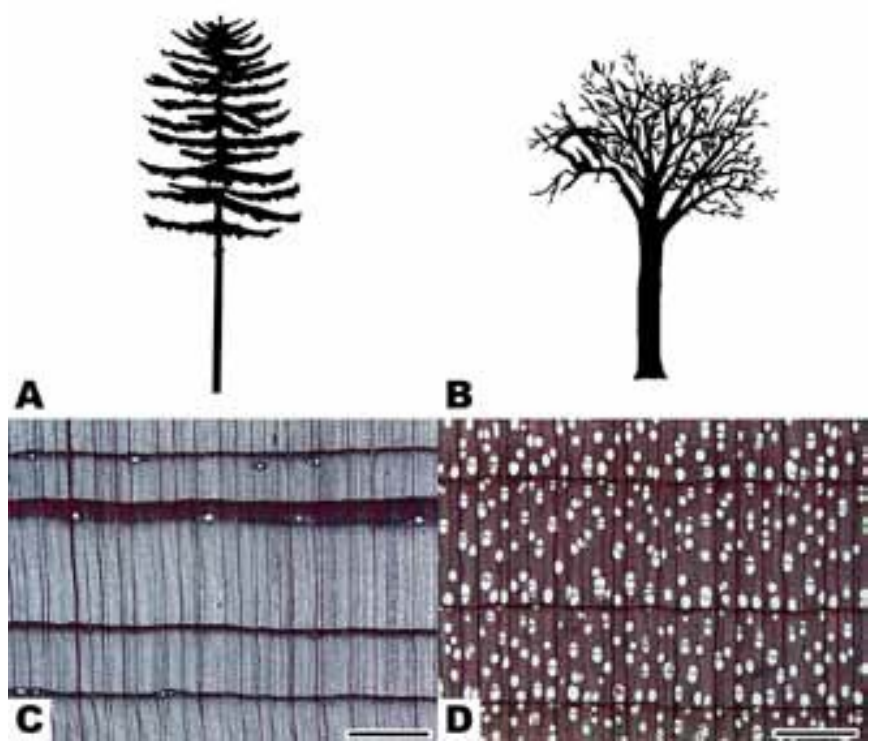

Figure 1. Generic shape of a softwood (A) and hardwood (B) and the corresponding microstructure (in cross section) of a softwood (C) and hardwood (D). Scale bar represents $780 \mu \mathrm{m}$. From [1].

and lignin, in roughly the same proportions [9]. In addition to the structural polymers, wood also contains a wide range of extractives, or chemicals that can be removed from the wood with various solvents. The types and amounts of extractives vary widely between wood species, and some of these extractives can affect the corrosion of embedded fasteners (see Section "Role of wood chemistry on corrosion").

Given the porous microstructure and relatively benign chemistry, wood may not seem like a challenging environment for corrosion. However, wood has complex interactions with water that greatly affect its physical, mechanical, and chemical properties, including corrosion. Wood is a hydrophilic material and can hold over $200 \%$ of its dry weight as water [10]. Moisture can exist in wood as free water (liquid water or water vapor in cell lumina and cavities) or as bound water (held by intermolecular forces within cell walls). The moisture content at which only the cell walls are completely saturated (all bound water) but no water exists in cell lumina is called the fiber saturation point. The fiber saturation point occurs at approximately $30 \%$ moisture content (MC, weight of water/weight of dry material) for many wood species [11].

In the absence of liquid water (and the resulting capillary water uptake), wood freely exchanges moisture with its environment until it reaches an equilibrium (that depends upon the relative humidity). The relationship between equilibrium moisture content and relative humidity at a given temperature is called a sorption isotherm. The sorption isotherm depends on the wood species and previous history of the wood, however the data in Figure 2 are frequently used for practical purposes to estimate moisture content for a given relative humidity and temperature in the absence of better data [10]. 


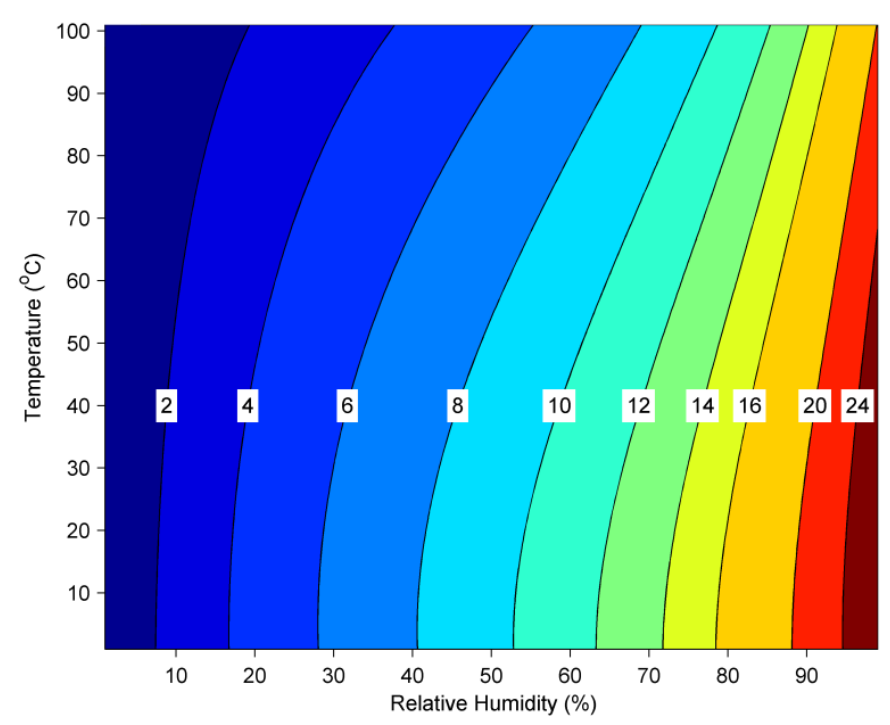

Figure 2. Moisture content (contours) as a function of relative humidity and temperature; data represent an average of adsorption/desorption and should be used for approximations only [3].

Even below fiber saturation, bound water is able to solvate and conduct ions. Zelinka et al. showed that ionic conduction in wood is a percolation phenomenon and that at approximately $16 \% \mathrm{MC}$, there is a continuous pathway for ion conduction in wood [12]. For reference, $16 \%$ MC corresponds with a relative humidity range of approximately 75\%-85\% [13]. The percolation threshold is related to a threshold moisture content for corrosion of metals in contact with wood (see Section "Role of wood moisture content on corrosion").

\section{Wood preservatives}

Wood preservatives are chemicals that are injected into the wood to help the wood resist attack by decay fungi, mold, and/or termites. Waterborne wood preservatives are commonly used when the wood may be in contact with humans or will be painted. Although many different formulations of waterborne preservative treatments have been developed, only a few of these have been used commercially. Most commercial treatments contain cupric ions, which give treated wood its characteristic greenish-brown coloration (Figure 3).

In 2004, regulation changes in the United States restricted the use of chromated copper arsenate (CCA), which had previously dominated the preservative market for many years. Similar regulation changes happened in the European Union and Australasia. Since the regulation change, alternatives to CCA have been introduced to the market. A brief summary of the commercially important alternative wood preservatives is provided below; more information is available in references $[2,3]$. Although the exact formulations of the newer wood preserva- 


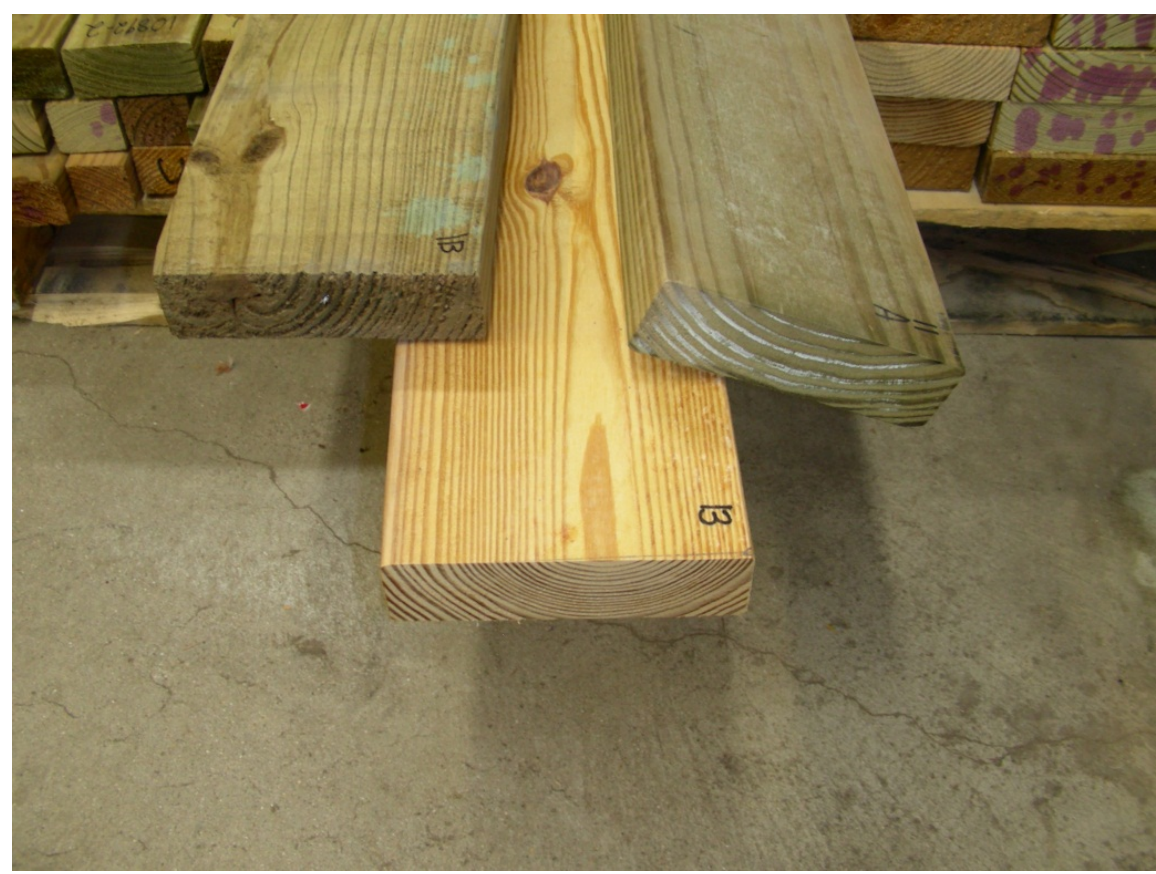

Figure 3. (From left to right) Wood treated with MCQ, DDAC, and ACQ. Cupric ions from the wood preservative cause the dark coloration of the wood. Excess copper has deposited on the MCQ (green splotches) and the ACQ (along the end grain) samples. SCALE: The boards are approximately $38 \times 140 \mathrm{~mm}$.

tives are different from each other, they are similar in that they all have a higher percentage of copper than that of CCA. This is important because the corrosion mechanism involves the reduction of cupric ions from the preservative and the corrosion rate depends upon cupric ion concentration [14].

Alkaline copper quaternary (ACQ) is composed of copper oxide $(67 \%)$ and a quaternary ammonium compound (DDAC- didecyldimethylammonium chloride or carbonate 33\%). When it was first commercially available, the quaternary ammonium compound was made with a chloride formulation but was later almost exclusively replaced with a carbonate formulation. Several formulations of ACQ have been commercialized, and it can be treated with an amine or ammonia carrier.

Copper azole (CA) types B and C are composed of ammine copper $(96 \%)$ and an azole $(4 \%)$. In CA type B, the azole is entirely composed of tebuconazole. In type C, the azole is 50/50 mixture of tebuconazole and propiconazole. Although copper azole contains a higher percentage of copper than does ACQ, the retention required for aboveground use (Category U3 [15]) is lower and, therefore, the total amount of copper in the treated wood is less.

In addition to these preservatives (CCA, ACQ, CA) standardized by the American Wood Protection Association, several commercially important preservatives have been introduced 
to the market by ICC-ES evaluation reports. These preservatives include "micronized" formulations of ACQ and CA, which have various trade names. In these formulations, soluble copper is not injected into the wood, rather solid copper, copper oxide, or copper carbonate is ground into submicron particles, or "micronized," and suspended in solution prior to injection. Several different formulations of these preservatives are covered by different ICC-ES evaluation reports. These formulations differ in listed uses and required retentions and have slight differences in formulations, but in general require less copper than the nonmicronized counterparts.

A summary of wood preservatives highlighting copper concentration is given in Table 1 . Preservative composition is given in column 2; aboveground retention needed to meet Use Category $3 b$ for aboveground use according to AWPA U1 is given in column 3 [15]. Column 4, calculated from columns 2 and 3, lists the amount of copper metal per volume of wood. Several studies have shown that as copper concentration in the wood is increased, corrosion of metal fasteners increases $[4,16]$.

\begin{tabular}{|c|c|c|c|}
\hline Preservative & Composition & $\begin{array}{c}\text { Aboveground retention } \\
\text { (kg of preservative per } \mathrm{m}^{3} \\
\text { of wood) }\end{array}$ & $\begin{array}{c}\text { Copper concentration } \\
\text { ( } \mathrm{g} \text { of copper per } \mathrm{m}^{3} \text { of } \\
\text { wood) }\end{array}$ \\
\hline \multirow{3}{*}{ CCA } & $47.5 \%$ chromium trioxide & \multirow{3}{*}{4} & \multirow{3}{*}{591} \\
\hline & $34.0 \%$ arsenic pentoxide & & \\
\hline & $18.5 \%$ copper as copper oxide & & \\
\hline \multirow{2}{*}{ ACQ } & $67 \%$ copper as copper oxide & \multirow{2}{*}{4} & \multirow{2}{*}{2141} \\
\hline & $33 \%$ DDAC & & \\
\hline \multirow{2}{*}{ CA-B } & $96.1 \%$ amine copper as $\mathrm{Cu}$ & \multirow{2}{*}{1.7} & \multirow{2}{*}{1634} \\
\hline & 3.9\% Tebuconazole & & \\
\hline \multirow{3}{*}{ CA-C } & $96.1 \%$ amine copper as $\mathrm{Cu}$ & \multirow{3}{*}{1.0} & \multirow{3}{*}{961} \\
\hline & 1.95\% Tebuconazole & & \\
\hline & 1.95\% Propiconazole & & \\
\hline \multirow{2}{*}{ ESR-1721 (MCA-B) } & $96.1 \%$ amine copper as $\mathrm{Cu}$ & \multirow{2}{*}{1.0} & \multirow{2}{*}{961} \\
\hline & 3.9\% Tebuconazole & & \\
\hline \multirow{3}{*}{ ESR-1721 (MCA-C) } & $96.1 \%$ amine copper as $\mathrm{Cu}$ & \multirow{3}{*}{0.8} & \multirow{3}{*}{769} \\
\hline & 1.95\% Tebuconazole & & \\
\hline & 1.95\% Propiconazole & & \\
\hline \multirow{2}{*}{ ESR-1980 } & $67 \%$ copper as copper oxide & \multirow{2}{*}{2.4} & \multirow{2}{*}{1285} \\
\hline & $33 \%$ DDAC & & \\
\hline \multirow{2}{*}{ ESR-2240 } & $25 / 26$ copper particles & \multirow{2}{*}{1.0} & \multirow{2}{*}{961} \\
\hline & 1/26 Tebuconazole & & \\
\hline
\end{tabular}

Table 1. Summary of some waterborne wood preservatives and aboveground retentions highlighting the difference in copper concentration between preservatives. Data are combined from ([17, 18]). 


\section{Mechanism of corrosion in wood treated with copper-containing wood preservatives}

Many of the concerns over corrosion of metals in treated wood involve wood treated with copper-based wood preservatives (e.g., those in Table 1). For wood treated with these preservatives, the corrosion mechanism involves the reduction of cupric ions available in the wood, which are reduced as the construction material, normally a steel or zinc galvanized connector, is oxidized. Figure 4 illustrates this mechanism of corrosion highlighting the transport of cupric ions to the metal surface, where there is a charge transfer reaction resulting in oxidation of the fastener and reduction of the cupric ions in the wood preservative.

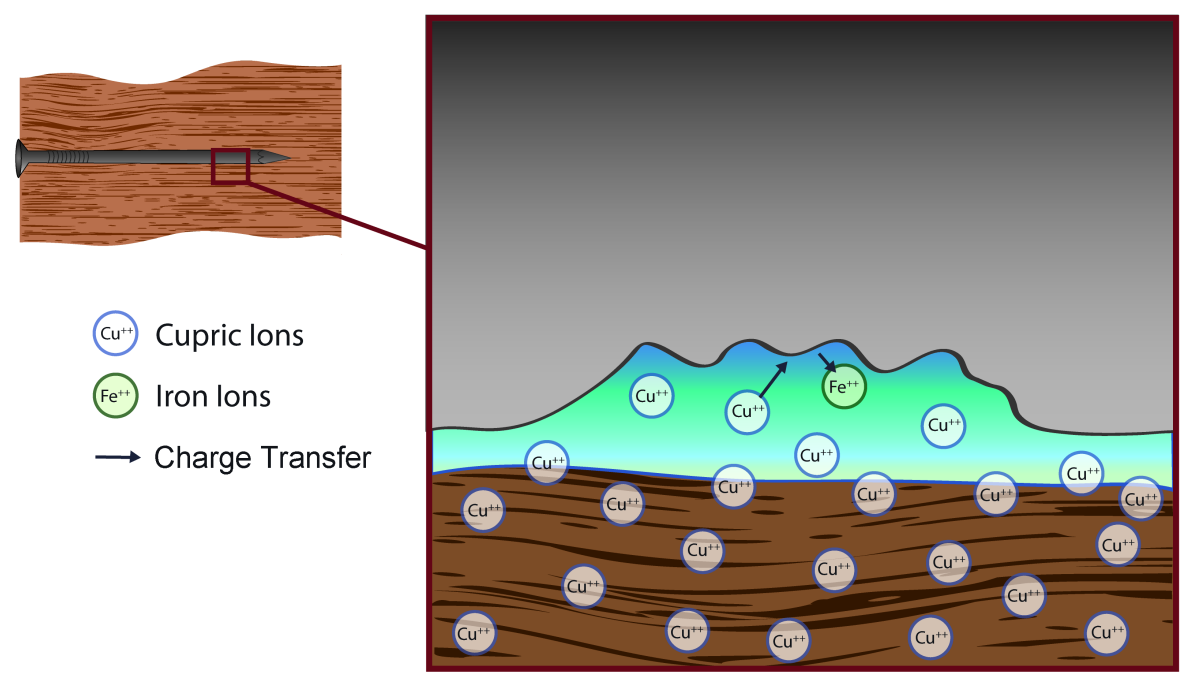

Figure 4. Schematic illustration of the mechanism of corrosion in treated wood (not to scale).

The role of cupric ions in the corrosion mechanism was first hypothesized by Baker [19] and later confirmed by work of Zelinka et al. [5, 14] and Kear et al. [4, 20] through energy dispersive $\mathrm{x}$-ray analysis, Pourbaix diagrams, and examinations of the role of cupric ion concentration and acidity. Zelinka et al. performed electrochemical corrosion tests in water extracts of treated wood, which were later found to result in similar corrosion rates to those measured in solid wood $[6,14,21]$. Because the medium was aqueous and electrochemical techniques were used, ion concentrations, $\mathrm{pH}$, and potentials could be measured and a Pourbaix diagram could be constructed. Figure 5 shows the Pourbaix diagram of copper with measured potentials in extracts of wood treated with different wood preservatives. The diagram shows that zincgalvanized steel lies in a region where copper metal is the stable phase, and therefore cupric ions in the preservatives are thermodynamically unstable. Further work using energy dispersive x-ray spectroscopy (EDS) showed that fasteners placed in the extract had copper metal deposited on them. 


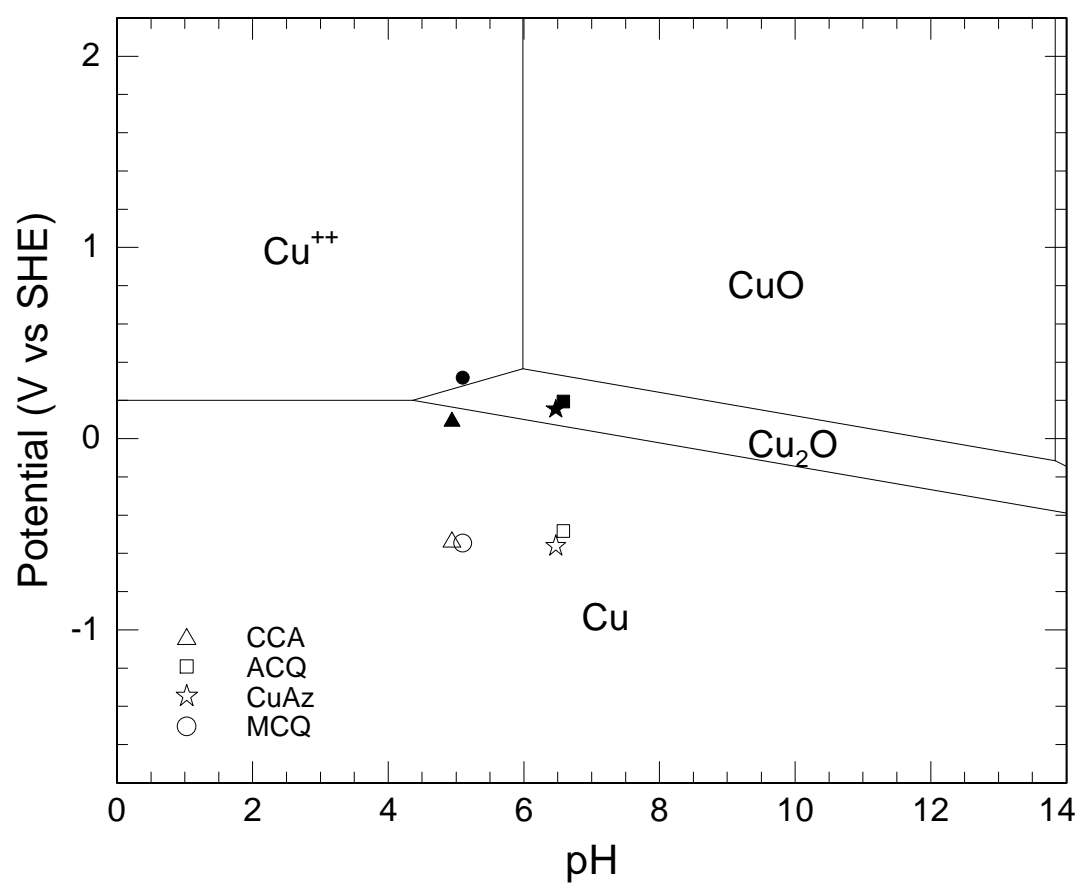

Figure 5. Pourbaix diagram with an assumed cupric ion concentration of $10^{-4}$ with the open circuit potentials of steel (filled symbols) and galvanized steel (open symbols) in water extracts of different wood preservatives.

Several researchers have shown that corrosion rate of metals in treated wood increases with increasing cupric ion concentration $[4,14,16]$. The clearest evidence of this was found in an unpublished report by the Forest Products Laboratory, the results of which were synthesized and republished by Zelinka and Rammer [16]. In these experiments, living trees were allowed to imbibe a copper-containing wood preservative before felling, and corrosion rate was measured in logs cut from these trees; corrosion rate quadrupled as copper concentration increased from 1 to $11 \mathrm{~kg} \mathrm{~m}^{-3}$. Zelinka and Stone [14] examined differences in corrosion rates observed in different wood preservatives and showed that most differences could be explained by differences in cupric ion concentration and $\mathrm{pH}$ (MCQ, CCA were acidic, ACQ was alkaline). For example, at a given copper concentration, the preservative with the lower $\mathrm{pH}$ was more corrosive. Similarly, at a given $\mathrm{pH}$, the preservative with the higher copper concentration was more corrosive.

Despite the fact that the corrosion mechanism clearly involves reduction of cupric ions in the preservative, several experiments that examined corrosion products of fasteners embedded in treated wood found no evidence of copper metal on the fasteners [5, 6]. This raises the question of what is happening to the reduced cupric ions: do they get bound to the wood near the metal surface, or do they get reoxidized or redissolved in a different reaction step? Further research is needed to explain this enigma. 


\section{Role of wood moisture content on corrosion}

The most important environmental variable controlling corrosion of metals embedded in wood is moisture content of the wood. Below a threshold moisture content of $15 \%-18 \% \mathrm{MC}$, embedded metals do not corrode [12, 22-24]; above the threshold, corrosion rate increases with moisture content and plateaus at a maximum corrosion rate near or above fiber saturation point. Despite the importance of wood moisture content on corrosion rate, very little research has been conducted to examine the role of moisture on corrosion.

Two different long-term exposure tests examined the role of wood moisture content on corrosion by placing wood with embedded fasteners in chambers with a fixed relative humidity. Baechler $[25,26]$ used three chambers at 30\%, 65\%, and 90\% RH. Kear et al. [4] examined $75 \%$ and $90 \% \mathrm{RH}$ and "moisture saturated air." In these studies, corrosion rate was effectively zero at 30\% and $65 \% \mathrm{RH}$ and barely measureable at $75 \% \mathrm{RH}$. Corrosion rate then had noticeable increases between both the $75 \%$ and $90 \% \mathrm{RH}$ and the $90 \% \mathrm{RH}$ and moisture saturated air conditions.

The number of moisture contents at which a gravimetric corrosion rate can be determined is limited experimentally by time, expense, and difficulty maintaining the wood moisture content constant for long periods of time. To develop a more detailed curve, Dennis et al. used electrochemical tests to measure corrosion rate as a function of moisture content in solid wood treated with CCA [22]. In these tests, thin sheets of wood were pressed around a zinc working electrode and stainless steel counter electrode and corrosion rate was measured with the polarization resistance technique. A subset of the data are plotted in Figure 6. The data exhibit hysteresis with moisture content, which suggests that the wood specimens were not in equilibrium when measurements were taken. These data have been used to create a combined hygrothermal/corrosion model to predict the amount of corrosion one can expect in different environments [27]. The model calculates wood moisture content from hourly climatic data and calculates the hourly amount of corrosion from the wood moisture content.

\section{Differences between atmospheric corrosion and corrosion of metals in wood products}

Corrosion of metals embedded in wood has several differences from atmospheric corrosion, with implications for both materials selection and service life of metals in wood. The two most important differences are that (1) galvanized steel corrodes more rapidly than carbon steel when in contact with wood and (2) long-term corrosion kinetics are different in wood than in atmospheric conditions. Both of these differences can be attributed to the fact that corrosion products of metals in contact with wood are different than those that form in atmospheric conditions and therefore the passivation is different.

In atmospheric corrosion, zinc oxidizes to form hydrozincite $\left\{\mathrm{Zn}_{5}\left(\mathrm{CO}_{3}\right)_{2}(\mathrm{OH})_{6}\right\}$ and smithsonite $\left(\mathrm{ZnCO}_{3}\right)$, which passivate the zinc surface; that is, these oxidized species protect the metal from 


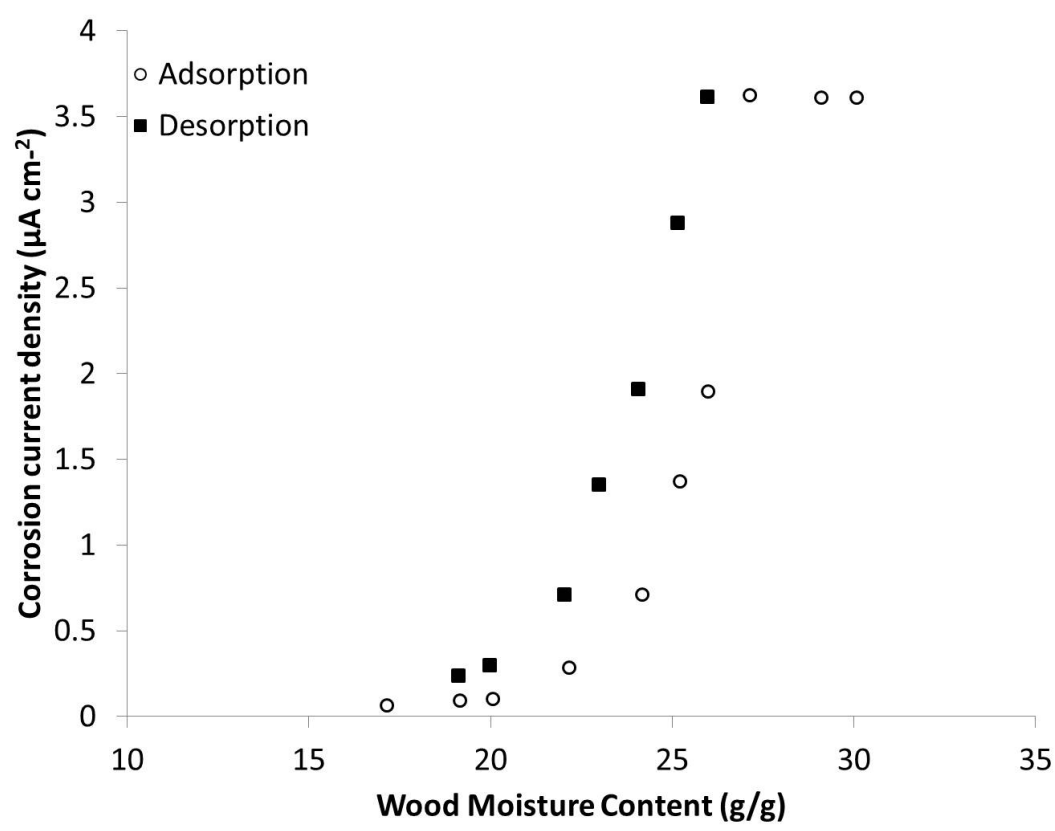

Figure 6. Selected data of Dennis et al. replotted to show the dependence of corrosion rate on wood moisture content. Data from [5].

further corrosion. Conversely, steel forms goethite $(\alpha-\mathrm{FeOOH})$, also called "red rust" in atmospheric conditions. Kinetically, hydrozincite and smithosnite are better at protecting the underlying metal than goethite, which is why zinc corrodes more slowly than steel in atmospheric conditions [28]. In certain environments, such as immersion in saltwater [29] or in environments with volatile acetic and formic acids [30], different corrosion products form and zinc corrodes more rapidly than steel. In addition to measuring corrosion rates, Zelinka et al. [5] examined corrosion products on fasteners removed from steel and galvanized steel fasteners in wood using X-ray diffraction and did not observe smithsonite on the zinc fasteners. Instead, they observed namuwite $\left\{\mathrm{Zn}_{2}\left(\mathrm{SO}_{4}\right)(\mathrm{OH})_{6} 4 \mathrm{H}_{2} \mathrm{O}\right\}$, simonkolleite $\left\{\mathrm{Zn}_{5}(\mathrm{OH})_{8} \mathrm{Cl}_{2}(\mathrm{H} 2 \mathrm{O})\right\}$, and in some cases hydrozincite. The lack of a protecting passive layer explains why galvanized fasteners corrode more rapidly than steel fasteners in solid wood.

Passivation in atmospheric corrosion also causes a decrease in corrosion rate with time. Legault and Preban described corrosion kinetics under atmospheric conditions by

$$
\Delta W=K t^{n}
$$

where $\Delta W$ is the change in weight, $K$ is a constant (the 1-year corrosion rate), $t$ is time in years, and $n$ is an exponent that controls the kinetics and is less than or equal to unity [31]. Corrosion 
of metals in wood exhibits a constant rate with time (i.e., $n=1$ ). This behavior was first observed by Baker [32], who found that the weight loss increased linearly with time in a 17-year exposure test. Zelinka et al. observed further evidence of activation control in measurements performed in water extracts of treated wood. They observed that corrosion rates measured in the extract were similar to those measured in solid wood, where the diffusion is slower [33].

\section{Role of wood chemistry on corrosion}

Even a single species of wood can have more than 700 different extractives, chemicals that can be solubilized in water or another solvent, and could, in theory, affect the corrosion of embedded metals [34]. Despite the large number of extractives that could potentially affect corrosion, very few of these compounds have been associated with corrosion of embedded metals. Zelinka and Stone [35] reviewed the literature on the role of extractives on corrosion and found that previous researchers had identified only three different compounds that affect corrosion of metals embedded in wood or exposed to the black liquors of wood pulp: small organic acids (acetic and formic acid) [30, 36-39], tannins (or more broadly, polyphenols) [34, 40-49], and phenols with two or three adjacent hydroxyl groups (e.g., catechol and pyrogallol) [45-50]. For solid wood, only organic acids and tannins have been mentioned in the literature; catechol (1,2-dihydroxybenzene) and pyrogallol (1,2,3-trihydroxybenze) are formed as lignin is destroyed in the pulping process $[51,52]$.

Zelinka and Stone further investigated the role of tannins and $\mathrm{pH}$ by making water extracts of different wood species known to vary in both tannin content and $\mathrm{pH}$ : pine (low $\mathrm{pH}$, low tannin), oak (low $\mathrm{pH}$, high tannin), elm (high $\mathrm{pH}$, low tannin), and black locust (high $\mathrm{pH}$, high tannin). A blue-black precipitate formed on the surface of steel in the extracts, suggesting the formation of a passive layer of iron-tannate (Figure 8). In further experiments they adjusted the extracts by changing the amount of tannins or the $\mathrm{pH}$. In these experiments they observed that at a given $\mathrm{pH}$, increasing the tannins decreased the corrosion rate; and at a given level of tannins, lowering the $\mathrm{pH}$ increased the corrosion rate. Based upon their measurements and simple kinetic models, Zelinka and Stone developed an isocorrosion map for the water extracts of different wood species (Figure 7). While absolute corrosion rates are higher than would be expected in solid wood, the same general trends are expected to apply.

\section{Test methods to examine corrosion of metals in wood}

One year after the 2004 regulation change in wood preservatives, Zelinka and Rammer [53] summarized 22 different methods that had been previously used to evaluate corrosion of metals in contact with wood. The review was divided into "exposure tests," where temperature and relative humidity were kept near realistic conditions, "accelerated tests," where temperature and/or a fog were used to accelerate corrosion, and "electrochemical tests," where the metal was polarized to evaluate corrosion rate. In general, many of the tests were for "com- 


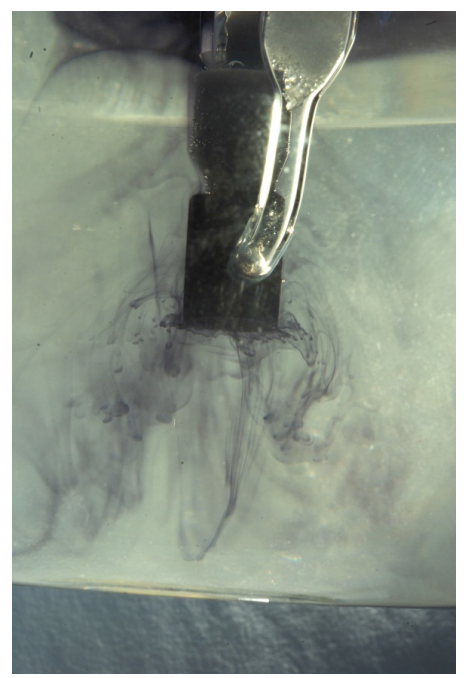

Figure 7. Iron-tannate precipitate forming on a steel plug in a solution with the same tannin concentration and $\mathrm{pH}$ as white oak. SCALE: The steel plug is approximately $9.5 \mathrm{~mm}$ in diameter.

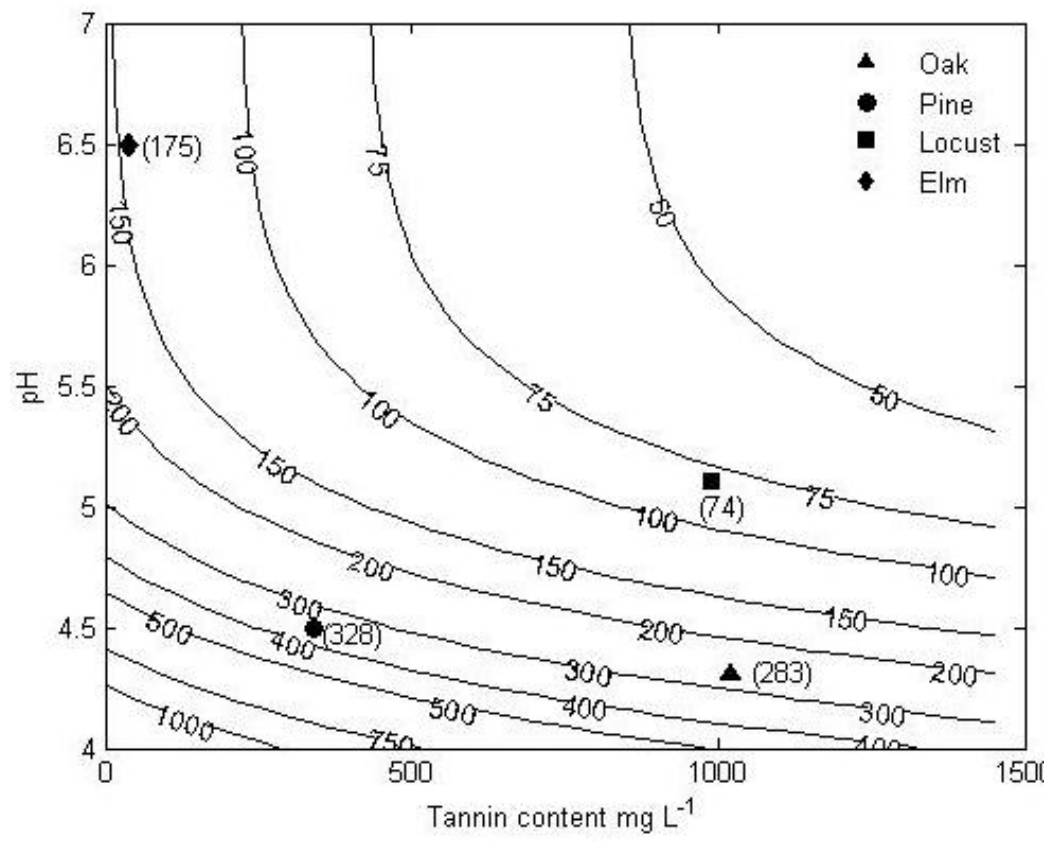

Figure 8. Showing the interplay between tannins (abscissa) and pH (ordinate). Contours represent combinations of tannins and $\mathrm{pH}$ that result in the same corrosion rate 
parative purposes only," where conclusions could be drawn only between a treatment and a control group. In many cases, corrosion was reported as a percentage weight loss instead of a true corrosion rate because the surface area of threaded fasteners could not be calculated. It has been shown that this way of reporting corrosion rates distorted the performance of aluminum fasteners, which have a lower density than steel and galvanized steel fasteners [7].

Since the Zelinka and Rammer review of test methods, several new test methods have been developed. A new standard has been written to measure the corrosion rates of fasteners driven into treated wood [54], and the American Wood Protection Association (AWPA) E-12 standard has been greatly revised [55]. Furthermore, Rammer and Zelinka developed a method to calculate the surface area of threaded fasteners from digital images [56-58], which allows for true corrosion rates to be measured. The remainder of this section summarizes new developments in test methodologies.

AWPA standard E12, "Standard method of determining corrosion of metal in contact with treated wood," was the first standardized test method used to measure corrosion of metals in contact with wood [55]. The test method places metal coupons between two blocks of treated wood and exposes the "sandwich" to a high-temperature $\left(50^{\circ} \mathrm{C}\right)$ high-humidity $(90 \% \mathrm{RH})$ environment for 120 days. The blocks of wood are held together with nylon bolts. The E12 standard was revised and greatly improved in 2008. The new standard specifies an effective torque for the nylon bolts and gives much more detailed instructions for cleaning the corrosion products. Although the E12 test can be used to make a relative ranking between preservatives, information on the effect of temperature on the corrosion of embedded metals is lacking and it is impossible to relate corrosion rates measured in the E12 test to realistic temperatures for building enclosures or outdoor wood structures.

ASTM International standard G198, "Standard test method for determining the relative corrosion performance of driven fasteners in contact with treated wood," was published in 2011 [54]. The goal was to develop a test method to evaluate fasteners, which may have different metallurgical characteristics or coatings than the sheet metal used in the AWPA E12 test. Beyond the geometry of the metal sample, the biggest difference between the ASTM and AWPA standards is the exposure conditions. The AWPA test is conducted at a temperature of $50^{\circ} \mathrm{C}$; the ASTM test is conducted at a lower and potentially more realistic temperature of $32^{\circ} \mathrm{C}$. Relative humidity conditions are also different between the two standards. In the ASTM test, the wood and fasteners are exposed either to a "steady state" test of 95\% RH or to a "cyclic fog" test where the fasteners are exposed to 48 hours of fog followed by a 72-hour dry cycle. Both tests are conducted for 120 days. The reasoning for including a cyclic fog test is that in accelerated testing conditions, galvanized fasteners perform better when exposed to alternating wet and dry cycles, which is similar to the environment they see in service [28, 29]. However, Zelinka recently showed that wood acts as a moisture buffer and does not dry out during the dry cycles; rather, it gains moisture throughout the entire test [59]. From this analysis it appears that the cyclic fog test may be more challenging than the steady-state moisture test.

Results of several exposure tests in newer wood preservatives have been reported as actual corrosion rates rather than percentage weight loss. Kear et al. exposed nails and metal coupons to treated wood exposed to three different relative humidity environments [4] (75\% RH, 90\% 
$\mathrm{RH}$, "moisture saturated air"). The surface area of the nails was calculated from the diameter and tip geometry. Zelinka et al. measured the corrosion rates of screws and nails at $100 \%$ relative humidity [5, 7]. Furthermore, using photographs from Baker's laboratory notebook, Zelinka and Rammer were able to convert Baker's seminal data from a 17 year exposure test in CCA- and ACA-treated wood from percentage weight loss to actual corrosion rates [7].

Additional work has further advanced electrochemical methods as a rapid technique to measure corrosion of metals in treated wood. Both Zelinka et al. [60] and Kear et al. [61, 62] have measured corrosion of metal fasteners in dilute solutions of wood preservatives. Zelinka et al. used the polarization resistance technique and concluded that these measurements could not be used to predict corrosion of metals embedded in treated wood. Kear et al. used impedance spectroscopy, large perturbation potentiodynamic polarization, and polarization resistance measurements to characterize the corrosion performance of mild steel, stainless steel, and galvanized steel in dilute solutions of wood preservatives. Kear et al. observed good correlation between trends found in these electrochemical measurements and gravimetric measurements in dilute solutions of wood preservatives as specified in the AWPA E17 test for measuring the corrosiveness of wood treatment solutions [20, 63], but not for metals embedded in treated wood.

Although these measurements in dilute solutions of wood preservatives were unable to predict the corrosion of embedded metals, a different method developed by Zelinka et al. [6] has good correlation to laboratory exposure tests of metals in treated wood. In this method, extracts of treated wood were made by grinding the treated wood, adding water (1:10 weight ratio), and extracting the water-soluble components of the treated wood for one week, after which the milled wood was filtered off. The rationale for the method was that corrosion of embedded metals is aqueous and that the water extract would have a similar chemistry to the microchemistry within the wood structure. Corrosion rates determined from polarization resistance measurements in the extract had excellent correlation to corrosion rates of fasteners embedded in wood conditioned at $100 \%$ RH for 1 year [7].

\section{Review of corrosion rates measured in wood treated with different preservatives}

Since the 2004 change in wood preservative regulation, several investigations of the corrosiveness of metals in contact with treated wood have been reported. The studies cover a wide range of preservatives, preservative retentions, wood moisture contents, and metals tested. Not surprisingly, a wide variation in corrosion rates has been reported (e.g., from 2-113 $\mu \mathrm{m}$ $\mathrm{yr}^{-1}$ for galvanized steel in ACQ-treated wood). Table 2 summarizes the corrosion data. Because of the wide variations of test conditions used, it is best to compare results only within a single study or across different studies with very similar conditions. The remainder of this section summarizes how the data in Table 2 were obtained.

Many design recommendations for materials selection in wood are based off the recommendations of Baker [32], who conducted a 17-year investigation of corrosion of metal fasteners embedded into chromated copper arsenate (CCA) and ammoniacal copper arsenate (ACA) 
treated wood exposed either underground or in a room maintained near 100\% RH From these data, Baker concluded that at a minimum, hot-dip galvanized fasteners should be used in treated wood and cautioned against the use of aluminum fasteners. Importantly, Baker presented the corrosion data as percentage weight loss instead of corrosion rate because he could not calculate the surface area of threaded fasteners. Zelinka and Rammer reanalyzed Baker's data using data in Baker's laboratory notebook and an algorithm they had developed to measure surface area of threaded fasteners $[7,56,57]$. They found that when the corrosion rate was adjusted to a true corrosion rate, the corrosion rate of aluminum was in fact less than that of hot-dip galvanized steel.

Zelinka has published results of several different corrosion tests that were conducted at $27^{\circ} \mathrm{C}$ $\left(80^{\circ} \mathrm{F}\right)$ and $100 \% \mathrm{RH}[5,7,14,64]$. In one study [7], Zelinka and Rammer examined the corrosion of five different metal fasteners (carbon steel, hot-dip galvanized steel, electroplated galvanized steel, aluminum, and stainless steel) embedded in wood treated with ACQ-D to a retention of $4 \mathrm{~kg} \mathrm{~m}^{-3}$. They found that the corrosion rate of hot-dip galvanized steel was the highest (62 $\left.\mu \mathrm{m} \mathrm{yr}^{-1}\right)$. The corrosion rate of stainless steel was statistically indistinguishable from zero. In another study [5], steel and hot-dip galvanized steel fasteners were exposed to six different wood treatments: chromated copper arsenate (CCA-C), alkaline copper quaternary (ACQ-D), copper azole (CA-B), micronized copper quaternary (MCQ), and didecyldimethylammonium carbonate (DDAC, or the "quat" in ACQ and MCQ). ACQ was found to be the most corrosive to both steel and galvanized steel.

Kear et al. examined the corrosion of three different metals (316 stainless steel, hot-dip galvanized steel, and plain carbon steel) in three different preservatives (CCA, ACQ, and CA) treated to three different retention levels with four different test methodologies [4]. Retention levels were specified in a New Zealand standard that specifies a mass basis (i.e., $\mathrm{kg} / \mathrm{kg}$ ) instead of a density basis and therefore cannot be directly compared to traditional U.S. retentions (in $\mathrm{lbs} \mathrm{ft}^{-3}$ or $\mathrm{kg} \mathrm{m}^{-3}$ ). Differences in the corrosiveness of the preservatives were most apparent in a constant exposure to $90 \% \mathrm{RH}$.

Simpson Strong Tie corporation published a technical bulletin on the results of in-house AWPA-E12 [55] corrosion tests [65]. In this test method a metal plate is sandwiched between two blocks of wood and exposed to a high-temperature $\left(50^{\circ} \mathrm{C}\right)$, high-humidity $(90 \% \mathrm{RH})$ environment. They found that the corrosiveness of ACQ-D (carbonate) was roughly equivalent to that of CA, and both of these were more than twice as corrosive as CCA-C. They also found that ACZA was more than three times more corrosive than CCA and that borates were less corrosive than CCA. A footnote in the table mentioned that for micronized formulations like MCQ the "relative corrosiveness is somewhat lower than ACQ-D."

Copper napthenate is sometimes used as a preservative in timber bridges. Although no peerreviewed data on the corrosiveness of copper napthenate have been reported, Anthony Forest Products company published a technical bulletin with the results of AWPA E12 tests that compares both waterborne and oilborne formulations of copper napthenate against ACQ-D and CCA-C for mild steel, hot-dip galvanized steel, aluminum, and red brass [66]. Although no data are reported on variability between replicates, the data clearly suggest that either formulation of copper napthenate is much less corrosive than ACQ and possibly less corrosive than CCA (Table 2). This bulletin was published by a company that supplies products treated 
with copper napthenate; nevertheless, the data suggest that copper napthenate is much less corrosive than ACQ and less than or equal in corrosiveness to CCA.

\begin{tabular}{|c|c|c|c|c|}
\hline & Plain steel & $\begin{array}{l}\text { Hot-dip galvanized } \\
\text { steel }\end{array}$ & Stainless steel & Aluminum \\
\hline 17 years, $27 \mathrm{C}(80 \mathrm{~F})$, & & $9 \mid$ CCA I & $<1 \mid$ CCA I & $3|C C A|$ \\
\hline $100 \%$ RH $[7,32]$ & & $6 \mid C C A \|$ & $<1 \mid$ CCA II & $4 \mid C C A \|$ \\
\hline 1 year, 27 C (80 F), 100\% RH [7] & $34 \mid A C Q$ & 61|ACQ & 1|ACQ & $22 \mid \mathrm{ACQ}$ \\
\hline \multirow{6}{*}{1 year, 27 C (80 F), 100\% RH [5] } & $9.4 \mid C C A$ & $16.1 \mid C C A$ & & \\
\hline & 16.8|ACQ & $32.5 \mid \mathrm{ACQ}$ & & \\
\hline & $12.5 \mid \mathrm{mCQ}$ & 19.4|mCQ & & \\
\hline & $11.1 \mid C A-B$ & $28.9 \mid C A-B$ & & \\
\hline & $1.9 \mid \mathrm{DDAC}$ & $5.5 \mid \mathrm{DDAC}$ & & \\
\hline & $0.7 \mid$ Untreated & 4.4|Untreated & & \\
\hline \multirow{3}{*}{$\begin{array}{l}1 \text { year, } 27 \text { C (80 F), } \\
\text { "moisture saturated air" [4] }\end{array}$} & $62 \mid C C A$ & $26 \mid C C A$ & $\leq 1 \mid C C A$ & \\
\hline & $176 \mid A C Q-B$ & $113 \mid A C Q-B$ & $\leq 1 \mid A C Q-B$ & \\
\hline & $84 \mid C A-B$ & $87 \mid C A-B$ & $\leq 1 \mid C A-B$ & \\
\hline \multirow{3}{*}{1 year, 27 C (80 F), 90\% RH [4] } & $4 \mid C C A$ & $5 \mid C C A$ & $\leq 1 \mid C C A$ & \\
\hline & 45|ACQ-B & 26|ACQ-B & $\leq 1 \mid A C Q-B$ & \\
\hline & $14 \mid C A-B$ & $16 \mid C A-B$ & $\leq 1 \mid C A-B$ & \\
\hline \multirow{3}{*}{1 year, 27 C (80 F), 75\% RH [4] } & $1 \mid C C A$ & $1 \mid C C A$ & $<1 \mid C C A$ & \\
\hline & $3 \mid A C Q-B$ & 2|ACQ-B & $<1 \mid A C Q-B$ & \\
\hline & $2 \mid C A-B$ & $2 \mid C A-B$ & $<1 \mid C A-B$ & \\
\hline \multirow{4}{*}{ AWPA E12 [66] } & $4 \mid C u N-W$ & $11 \mid \mathrm{CuN}-\mathrm{W}$ & & $(-1) \mid C u N-W$ \\
\hline & $1 \mid \mathrm{CuN}-\mathrm{O}$ & $2 \mid \mathrm{CuN}-\mathrm{O}$ & & $2 \mid \mathrm{CuN}-\mathrm{O}$ \\
\hline & 124|ACQ-D & $23 \mid A C Q-D$ & & 185|ACQ-D \\
\hline & $27 \mid C C A-C$ & 10|CCA-C & & 7|CCA-C \\
\hline \multirow{2}{*}{ AWPA E12 [67] } & $140 \mid \mathrm{mCA}$ & $23 \mid \mathrm{mCA}$ & & $18 \mid \mathrm{mCA}$ \\
\hline & $107 \mid C A$ & $51 \mid C A$ & & $(-3) \mid C A$ \\
\hline \multirow{5}{*}{ AWPA E12 [67] } & $66 \mid \mathrm{mCA}$ & $69 \mid \mathrm{mCA}$ & & $3 \mid \mathrm{mCA}$ \\
\hline & $180 \mid C A$ & $76 \mid C A$ & & 이CA \\
\hline & $41 \mid \mathrm{mCQ}$ & $41 \mid \mathrm{mCQ}$ & & O|mCQ \\
\hline & 196|ACQ-D & $81 \mid A C Q-D$ & & 3|ACQ-D \\
\hline & $41 \mid C C A-C$ & $53 \mid C C A-C$ & & $3 \mid C C A-C$ \\
\hline \multirow{3}{*}{ AWPA E12 [67] } & $89 \mid \mathrm{mCQ}$ & $25 \mid \mathrm{mCQ}$ & & 10|mCQ \\
\hline & 307|ACQ-D & 28|ACQ-D & & 10|ACQ-D \\
\hline & $76 \mid C C A-C$ & 20|CCA-C & & $5 \mid C C A-C$ \\
\hline
\end{tabular}

Table 2. Summary of published corrosion rates (in $\mu \mathrm{m} \mathrm{yr}^{-1}$ ) in treated wood. The table represents a wide variety of test methodologies-comparisons should be made only within a single row.

Freeman and McIntyre [67] summarized results of several unpublished corrosion tests of pressure-treated wood in contact with different metals that compared traditional (ACQ and 
CA) against their micronized formulations (MCQ and mCA). Most of the data shown were from AWPA E-12 tests. The results were inconclusive. In one test, the micronized formulation of CA was less corrosive than the standard formulation for galvanized steel but more corrosive for plain carbon steel, and the micronized formulation was much more corrosive to aluminum. The remainder of the E-12 data have similar trends; in some cases the micronized formulations show lower corrosiveness, in other cases, the traditional formulations appear less corrosive. The only results that consistently show that the micronized formulations are less corrosive than the traditional formulations are from a test conducted using a protocol from the International Staple and Nail Tool Association (ISANTA). In this test, the micronized formulations appear slightly (approximately 30\%-40\%) less corrosive, with the notable exception of aluminum, in which case the micronized formulations are more corrosive.

Table 2 summarizes corrosion rates measured in a variety of test methods over a range of wood preservatives and metals. Each row in the table represents a paper or report, and the test method is briefly summarized in the first column. Corrosion rates for each metal are contained in columns followed by the type of wood preservative. The data can be used for observing general trends or relative comparison of a preservative or a metal type; however, it is dangerous to compare across rows because different test methods were used.

\section{Effects of corrosion on the structural capacity of connections}

The main effect of corrosion of fasteners embedded in wood is to reduce the strength of the connection. Recently, Zelinka and Rammer used the yield theory equations and measured corrosion rates to calculate how fastener corrosion reduces the structural capacity of connections [68]. Fastener connection performance can be calculated by the yield theory developed by Johansen, which treats both the wood and metal as elastic/perfectly plastic materials [69]. The yield theory equations are now the standard method for calculating design capacity for any dowel type connector (nail, screw, lag screw, bolt, etc.) in the United States through the National Design Specification for Wood Construction (NDS). Lateral design load, Z (in N), is determined by

$$
Z=\min \left\{\begin{array}{rr}
\frac{D T_{\mathrm{s}} F_{\mathrm{es}}}{2.2} & \left(\text { Mode } \mathrm{I}_{\mathrm{s}}\right) \\
\frac{k_{2} D l_{\mathrm{p}} F_{\mathrm{em}}}{2.2\left(1+2 R_{\mathrm{e}}\right)} & \left(\text { Mode } \mathrm{III}_{\mathrm{m}}\right) \\
\frac{k_{3} D T_{\mathrm{s}} F_{\mathrm{em}}}{2.2\left(2+R_{\mathrm{e}}\right)} & \left(\text { Mode } \mathrm{III}_{\mathrm{s}}\right) \\
\frac{D^{2}}{2.2} \sqrt{\frac{2 F_{\mathrm{em}} F_{\mathrm{yb}}}{3\left(1+R_{\mathrm{e}}\right)}} & (\text { Mode IV })
\end{array}\right.
$$


where

$$
\begin{gathered}
k_{2}=-1+\sqrt{2\left(1+R_{\mathrm{e}}\right)+\frac{2 F_{\mathrm{yb}}\left(1+2 R_{\mathrm{e}}\right) D^{2}}{3 F_{\mathrm{em}} l_{\mathrm{p}}^{2}}} \\
k_{3}=-1+\sqrt{\frac{2\left(1+R_{\mathrm{e}}\right)}{R_{\mathrm{e}}}+\frac{2 F_{\mathrm{yb}}\left(2+R_{\mathrm{e}}\right) D^{2}}{3 F_{\mathrm{em}} T_{\mathrm{s}}^{2}}} \\
\text { and } \\
R_{\mathrm{e}}=F_{\mathrm{em}} / F_{\mathrm{es}}
\end{gathered}
$$

and $D$ is dowel diameter $(\mathrm{mm}), F_{\mathrm{e}_{-}}$is dowel bearing stress of the main $(\mathrm{m})$ or side $(\mathrm{s})$ member $(\mathrm{MPa}), F_{\mathrm{yb}}$ is bending yield stress of the nail $(\mathrm{MPa}), l_{\mathrm{p}}$ is length of penetration into main member, and $t_{\mathrm{s}}$ is thickness of the side member.

Zelinka and Rammer took measured corrosion rates and converted them to reduction in fastener diameter. Because corrosion does not affect joint geometry, wood dowel bearing stress, or bending yield stress of the uncorroded fastener, design load becomes a function of fastener diameter only. Zelinka and Rammer observed that for most decking fasteners, a Mode IV failure would be observed. This is especially problematic since Mode IV failure is the most sensitive to corrosion rate; design load scales as the diameter squared in this case. Figure 9 illustrates reduction in relative capacity of a nailed joint with time for different corrosion rates. For the range of measured corrosion rates in wood $\left(\sim 1-100 \mu \mathrm{m} \mathrm{yr}^{-1}\right)$, relative capacity drops quickly with increasing corrosion rate.

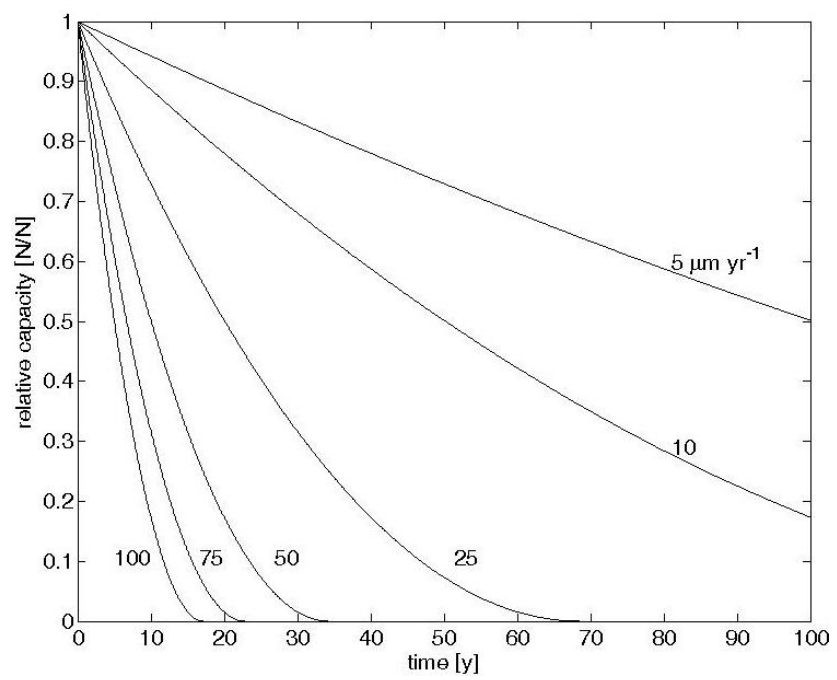

Figure 9. Loss of capacity as a function of time for different corrosion rates (labeled lines in $\mu \mathrm{m} \mathrm{yr}^{-1}$ ). The figure was constructed for a 3.4-mm nail exhibiting a Mode IV failure. 


\section{Design considerations for minimizing corrosion in wood}

Metal fasteners are an essential part of wood construction, and their use in preservative-treated wood cannot be avoided. Therefore, it is important to design and utilize metals in wood so that they exhibit the least amount of corrosion. Here we discuss three design considerations that will help prolong the service life of metals in wood: proper moisture management, proper use of nonmetallic coatings and barriers, and avoiding mixed metals in construction.

\subsection{Moisture management}

Proper moisture management is the most important factor in reducing corrosion of metals in treated wood. If wood is kept dry, both the wood and the fasteners can last for centuries [70]. In most cases, preservative-treated wood is specified because the wood will be exposed in an outdoor environment where it will be exposed to moisture. However, sound design principles can maximize drainage of rainwater and minimize the amount of moisture that is absorbed by the wood.

Clausen and Glass recently published a design guide for minimizing wood decay in residential construction by keeping the wood dry [70]. Pertinent strategies that also apply to exterior structures involve (1) keeping rainwater from seeping in through the end grain and (2) designing roofs and overhangs so they do not drain onto lower structures.

\subsubsection{End grain}

Moisture transport in the longitudinal direction (along the grain) is more than 10 times faster than in the radial or tangential directions. Therefore, if the end grain of the wood member is allowed to come into contact with liquid water, the entire member will absorb significant amounts of moisture. It is important to design the structure so that end grain is not exposed to water. This frequently happens at joints between two members if the connection is improperly designed or installed and the joint traps water. Vertical members (i.e., posts) are especially prone to water uptake along the end grain. For these members, impermeable coatings or end caps should be used to prevent water uptake through the end grain.

\subsubsection{Roof}

For outdoor wooden structures with a roof, such as covered bridges, proper roof design and detailing can shield much of the structure from water and keep the wood moisture content low. The larger the overhangs of the roof, the less likely it is that drainage from the roof will strike the walls below (Figure 10).

\subsection{Coated metals}

Paints and other nonmetallic coatings are frequently used to protect metals from corrosion by isolating the metal from the corrosive environment. The annual cost of coatings used to prevent corrosion is estimated at $\$ 100$ billion USD, which is 36\% of the total cost of corrosion in the 


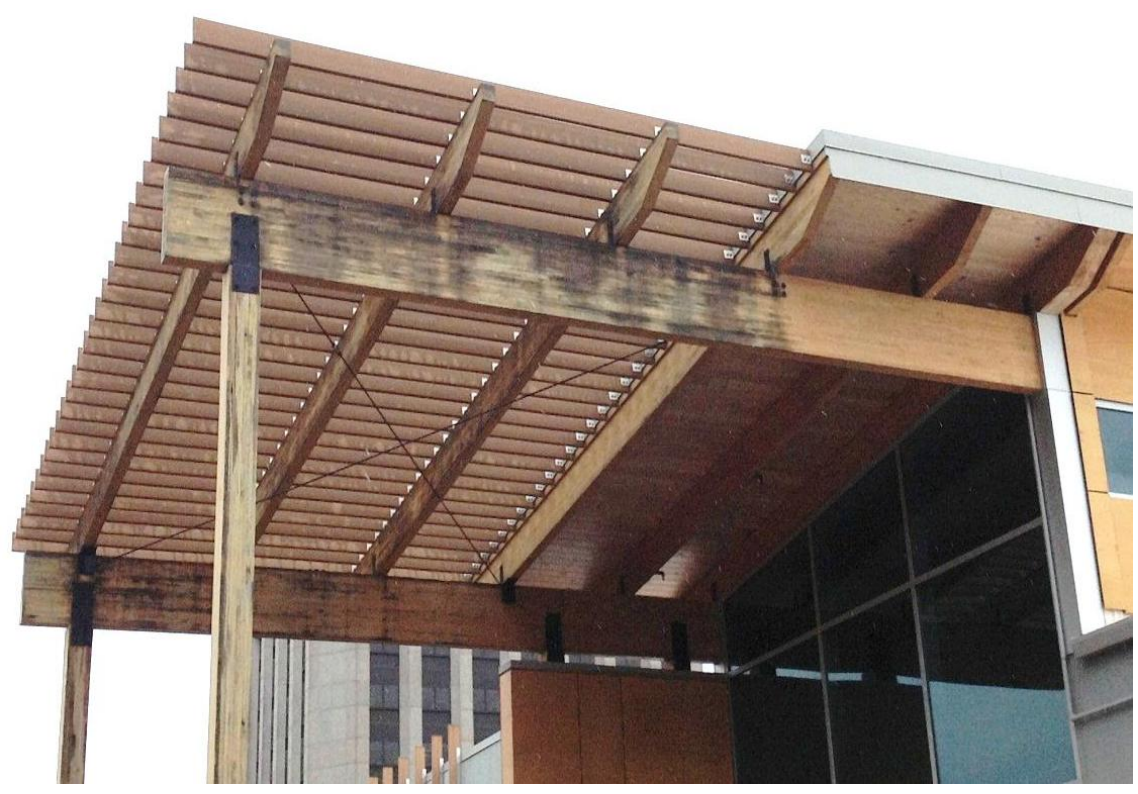

Figure 10. Illustration of the importance of roof overhangs for protecting wood from biodeterioration and corrosion. The right side of the beam is protected by the large roof overhang, whereas the left side is exposed to rain. SCALE: The beam supporting the trellis is $0.66 \mathrm{~m}$ deep.

Unites States and 1.1\% of the entire U.S. gross domestic product (GDP) [71]. Although many different formulations of organic coatings are available, the goal of nearly all coatings is to isolate the metal from the environment.

Coatings fail when the corrosive environment can reach the metal substrate. This can happen if the coating is mechanically damaged during installation (Figure 11). Zelinka et al. observed that screws with a nonmetallic coating had much worse corrosion performance after they had been driven into the wood or driven through a joist hanger into the wood [72] and attributed this decrease in performance to damage in the coating caused by inserting the fastener into wood. Extreme care should be taken if using coated metals in construction with wood so that the coating does not get damaged before or during installation.

\subsection{Mixed metals}

Special design consideration is needed if two different metals are used in contact with each other. Galvanic corrosion happens when three conditions are satisfied: (1) two dissimilar metals (2) are placed in electrical contact (3) in the presence of an electrolyte. Galvanic corrosion is a design concern in wood when a joist hanger or sign is attached to wood with a fastener. If the fastener is a different metal than the sheet metal, conditions for galvanic corrosion exist, wood acts as the electrolyte and the metals are in electrical contact between the head of the fastener and the sheet metal. 


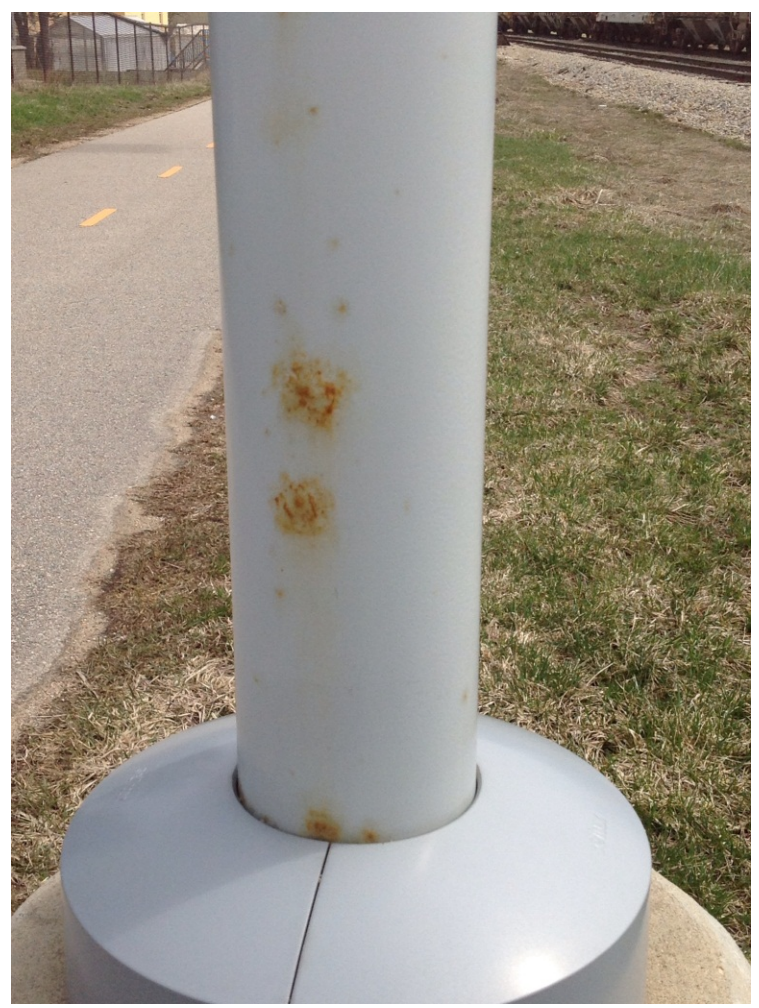

Figure 11. Corrosion underneath a coating failure. This lamp post was in service for less than 5 years before corrosion was visible at defects in the coating. SCALE: The lamp post is approximately $115 \mathrm{~mm}$.

An example of galvanic corrosion with wood was observed by the Wisconsin Department of Transportation (WisDOT) [73]. In this case, aluminum signs were attached to sign posts made of treated wood using galvanized lag screws. The aluminum signs exhibited excessive corrosion around the lag screw, causing the sign to fall off in some cases. In this case, aluminum was acting as the anode; the galvanized lag screw, the cathode; and wood, the electrolyte. Because it would be difficult to change the sign material, and aluminum lag screws do not exist, it is impossible, from a design perspective to change one of the metals to avoid corrosion. A better design solution would be to electrically isolate the aluminum sign from the galvanized lag screw.

\section{Conclusions}

This chapter summarized recent research on the corrosion of metals in wood focusing on how metals corrode in wood, how fast this corrosion occurs, and techniques to minimize corrosion in wood products. Despite the complexity of the corrosion mechanism in wood, the most 
important considerations for materials selection and design can be summarized in twoshort phrases:

"Corrosion in wood is not atmospheric corrosion" Corrosion in wood is different from atmospheric corrosion. There are different thermodynamics, different kinetics, and different corrosion products form. It is not safe to assume that just because a solution works for atmospheric corrosion that it is a good idea to apply it to fastener corrosion in wood.

"Keep the wood moisture content below 18\%" The corrosion of metals in wood is aqueous. The threshold moisture content at which moisture content occurs is between $15-18 \%$, and the corrosion rate experiences a steep transition around $20 \% \mathrm{MC}$. The structural degradation of the joint depends strongly upon the corrosion rate, so even a few percent moisture content difference can make a large difference in the service life of the fasteners.

\section{Author details}

Samuel L. Zelinka*

Address all correspondence to: szelinka@fs.fed.us

Materials Research Engineer, Durability and Wood Protection, US Forest Service, Forest Products Laboratory, Madison, USA

\section{References}

[1] A.L. Heim, G.M. Davidson, A.R. Joyce, Report of sub-committee 4 - corrosoin of fastenings, in, American Wood Preservers' Association, New Orleans, LA, 1923, pp. 373-379.

[2] S. Lebow, Alternatives to Chromated Copper Arsenate for Residential Construction. Res. Pap. FPL-RP-618, in, U.S.D.A. Forest Service, Forest Products Laboratory, Madison, WI, 2004, pp. 9-9.

[3] S. Lebow, Wood Preservation, in: Wood handbook- Wood as an engineering material, U.S. Department of Agriculture, Forest Service, Forest Products Laboratory, Madison, WI, 2010, pp. 508 p.

[4] G. Kear, H.-Z. Wu, M.S. Jones, Weight loss studies of fastener materials corrosion in contact with timbers treated with copper azole and alkaline copper quaternary compounds, Corrosion Science, 51 (2009) 252-262.

[5] S.L. Zelinka, R.J. Sichel, D.S. Stone, Exposure testing of fasteners in preservative treated wood: gravimetric corrosion rates and corrosion product analyses, Corrosion Science, 52 (2010) 3943-3948. 
[6] S.L. Zelinka, D.R. Rammer, D.S. Stone, Electrochemical corrosion testing of fasteners in wood extract, Corrosion Science, 50 (2008) 1251-1257.

[7] S.L. Zelinka, D.R. Rammer, Corrosion rates of fasteners in treated wood exposed to $100 \%$ relative humidity, ASCE Journal of Materials in Civil Engineering, 21 (2009) 758-763.

[8] A.C. Wiedenhoeft, Structure and Function of Wood, in: R.J. Ross (Ed.), U.S. Department of Agriculture, Forest Service, Forest Products Laboratory, 2010.

[9] J.F. Siau, V.P. Institute, S. University, Wood: Influence of moisture on physical properties, Department of Wood Science and Forest Products, Virginia Polytechnic Institute and State University Blacksburg, Virginia, 1995.

[10] S.V. Glass, S.L. Zelinka, Moisture Relations and Physical Properties of Wood, in: R.J. Ross (Ed.), U.S. Department of Agriculture, Forest Service, Forest Products Laboratory, 2010.

[11] S.L. Berry, M.L. Roderick, Plant-water relations and the fibre saturation point, New Phytologist, 168 (2005) 25-37.

[12] S. Zelinka, S. Glass, D. Stone, A Percolation Model for Electrical Conduction in Wood with Implications for Wood-Water Relations, Wood and Fiber Science, 40 (2008) 544-552.

[13] S.L. Zelinka, S.V. Glass, Water vapor sorption isotherms for southern pine treated with several waterborne preservatives, ASTM Journal of Testing and Evaluation, 38 (2010) 80-88.

[14] S.L. Zelinka, D.S. Stone, Corrosion of metals in wood: Comparing the results of a rapid test method with long-term exposure tests across six wood treatments, Corrosion Science, 53 (2011) 1708-1714.

[15] Anon, AWPA U1-06: Use category system, American Wood Preservers' Association, Granbury, TX, 2007.

[16] S.L. Zelinka, D.R. Rammer, Synthesis of Published and Unpublished Corrosion Data From Long Term Tests of Fasteners Embedded in Wood: Calculation of Corrosion Rates and the Effect of Corrosion on Lateral Joint Strength, in: CORROSION 2011, NACE International, Houston, TX, 2011, pp. Paper No. 11163.

[17] S.T. Lebow, Wood Preservation, in: R.J. Ross (Ed.), U.S. Department of Agriculture, Forest Service, Forest Products Laboratory, 2010.

[18] Anon, AWPA P5: Standard for waterborne preservatives, American Wood Preservers' Association, Granbury, TX, 2007.

[19] A.J. Baker, Corrosion of metals in preservative-treated wood, in: M. Hamel (Ed.) Wood Protection Techniques and the Use of Treated Wood in Construction, Forest Products Society, Madison, Wisconsin, 1988, pp. 99-101. 
[20] G. Kear, H.Z. Wú, M.S. Jones, Corrosion of ferrous- and zinc-based materials in CCA, ACQ, and CuAz timber preservative solutions, Materials and Structures, 41 (2008) 1405-1417.

[21] S.L. Zelinka, D.R. Rammer, D.S. Stone, Evaluating the corrosiveness of southern pine treated with several wood preservatives using electrochemical techniques, in: CORROSION 2009, NACE International, Atlanta, GA, 2009, pp. Paper \#09172.

[22] J.K. Dennis, C. Zou, N.R. Short, Corrosion behaviour of zinc and zinc alloy coated steel in preservative treated timber, Transactions of the Institute of Metal Finishing, 75 (1995) 96-101.

[23] N.R. Short, J.K. Dennis, Corrosion resistance of zinc-alloy coated steel in construction industry environments, Transactions of the Institute of Metal Finishing, 75 (1997) 47-52.

[24] A.J. Baker, Corrosion of metal in wood products, in: Durability of Building Materials and Components. ASTM STP 691., American Society for Testing and Materials, West Conshohocken, PA, 1980, pp. 981-993.

[25] R.H. Baechler, Corrosion of metal fastenings in zinc-chloride treated wood after ten years, in: Proceedings of the 35th Annual Meeting of the American Wood Preservers' Association, Washington, D.C., 1939, pp. 56-63.

[26] R.H. Baechler, Corrosion of metal fastenings in zinc-chloride treated wood after 20 years, in: Proceedings of the 45th Annual Meeting of the American Wood Preservers' Association, American Wood Preservers' Association, St. Louis, MO, 1949, pp. 381-397.

[27] S.L. Zelinka, D. Derome, S.V. Glass, Combining A Hygrothermal And Corrosion Model To Predict Corrosion Of Metal Fasteners Embedded In Wood, Building and Environment, 46 (2011) 2060-2068.

[28] X.G. Zhang, Corrosion of Zinc and Zinc Alloys, in: S.D. Cramer, B.S. Covino (Eds.) ASM Handbok Volume 13B, Corrosion:Materials, ASM International, Materials Park, $\mathrm{OH}, 2003$, pp. 402-417.

[29] X.G. Zhang, J. Hwang, W.K. Wu, Corrosion testing of steel and zinc, in: Proceedings of the 4th International Conference on Zinc and Zinc Alloy Coated Steel Sheet (GALVATECH '98), Chiba, Japan, 1998.

[30] D. Knotkova-Cermakova, J. Vlckova, Corrosive effect of plastics, rubber and wood on metals in confined spaces, British Corrosion Journal, 6 (1971) 17-22.

[31] R.A. Legault, A.G. Preban, Kinetics of the atmospheric corrosion of low-alloy steels in an industrial environment, Corrosion, 31 (1975) 117-122.

[32] A.J. Baker, Corrosion of nails in CCA- and ACA-treated wood in two environments, Forest Products Journal, 42 (1992) 39-41. 
[33] S.L. Zelinka, D.R. Rammer, D.S. Stone, Corrosion of metals in contact with treated wood: developing test methods, in: CORROSION 2008 NACE, New Orleans, LA, 2008, pp. Paper \#09172.

[34] P.E. Hazlewood, P.M. Singh, J.S. Hsieh, Role of wood extractives in black liquor corrosiveness, Corrosion, 62 (2006) 911-917.

[35] S.L. Zelinka, D.S. Stone, The effect of tannins and $\mathrm{pH}$ on the corrosion of steel in wood extracts, Materials and Corrosion, 62 (2011) 739-744.

[36] D.F. Packman, The acidity of wood, Holzforschung, 14 (1960) 178-183.

[37] C.A. Smith, Corrosion of metals by wood, Anti-Corrosion Methods and Materials, 29 (1982) 16-17.

[38] R.H. Farmer, Corrosion of metals in association with wood. Part 2. Corrosion of metals in contact with wood, Wood, 27 (1962) 443-446.

[39] E.T. Bartel-Kornacka, Corrosion of iron by Ghana timbers, Wood, 32 (1967) 39-42.

[40] A. Krilov, R. Gref, Mechanism of sawblade corrosion by polyphenolic compounds, Wood Science and Technology, 20 (1986) 369-375.

[41] H. Winkelmann, E. Badisch, M. Roy, H. Danninger, Corrosion mechanisms in the wood industry, especially caused by tannins, Materials and Corrosion, 60 (2009) $40-48$.

[42] H. Winkelmann, E. Badisch, S. Ilo, S. Eglsaer, Corrosion behaviour of tool steels in tannic acids, Materials and Corrosion, 60 (2009) 192-198.

[43] V.A. Pugsley, G. Korn, S. Luyckx, H.G. Sockel, On localised corrosive attack, stress corrosion cracking and corrosion fatigue effects in a hardmetal cutting-tool material, International Journal of Materials Research, 93 (2002) 745-749.

[44] V.A. Pugsley, G. Korn, S. Luyckx, H.G. Sockel, W. Heinrich, M. Wolf, H. Feld, R. Schulte, The influence of a corrosive wood-cutting environment on the mechanical properties of hardmetal tools, International Journal of Refractory Metals and Hard Materials, 19 (2001) 311-318.

[45] H. Maclean, J.A.F. Gardner, Heartwood extractives in digester corrosion, Pulp and Paper Magazine of Canada, 54 (1953) 125-130.

[46] S. Kannan, R.G. Kelly, The role of dihydroxybenzenes and oxygen on the corrosion of steel in black liquor, Corrosion Science, 38 (1996) 1051-1069.

[47] P.M. Singh, A. Anaya, Effect of wood species on corrosivity of black liquors, in, NACE International, Houston, Texas, 2001.

[48] P.M. Singh, A. Anaya, K. Frey, J. Mahmood, Corrosivity of black liquors- role of wood species pulped, in, VTT, Helsinki, Finland, 2001, pp. 409-425. 
[49] P.M. Singh, A. Anaya, Effect of wood species on corrosion behavior of carbon steel and stainless steels in black liquors, Corrosion Science, 49 (2007) 497-509.

[50] J. Gust, J. Suwalski, Use of Mössbauer spectroscopy to study reaction products of polyphenols and iron compounds, Corrosion, 50 (1994) 355-365.

[51] I.T. Clark, J. Green, Production of phenols by cooking kraft lignin in alkaline solutions, Tappi Journal, 51 (1968) 44-48.

[52] K. Niemelä, GLC-MS Studies on Pine Kraft Black Liquors Part V. Identification of Catechol Compounds, Holzforschung, 43 (1989) 99-103.

[53] S.L. Zelinka, D.R. Rammer, Review of test methods used to determine the corrosion rate of metals in contact with treated wood. Gen. Tech. Rp. FPL-GTR-156, U.S. Department of Agriculture, Forest Service, Forest Products Laboratory, 2005.

[54] Anon, ASTM G198 - 11: Standard Test Method for Determining the Relative Corrosion Performance of Driven Fasteners in Contact with Treated Wood, ASTM International, West Conshohocken, PA, 2011.

[55] Anon, AWPA E-12: Standard method of determining corrosion of metal in contact with treated wood, American Wood Preservers' Association, Selma, AL, 2007.

[56] D.R. Rammer, S.L. Zelinka, Optical method for measuring the surface area of a threaded fastener, Experimental Techniques, 34 (2010) 36-39.

[57] D.R. Rammer, S.L. Zelinka, Analytical determination of the surface area of a threaded fastener, ASTM Journal of Testing and Evaluation, 36 (2008) 80-88.

[58] D.R. Rammer, S.L. Zelinka, Algorithm to calculate the surface area of a threaded fastener. United States Patent No. 8,041,150, 2011.

[59] S.L. Zelinka, Comparing the Methodologies in ASTM G198: Is There an Easy Way Out?, in: CORROSION 2013, NACE International, Orlando, FL, 2013, pp. Paper Number 2507.

[60] S.L. Zelinka, D.R. Rammer, D.S. Stone, J.T. Gilbertson, Direct current testing to measure corrosiveness of wood preservatives, Corrosion Science, 49 (2007) 1673-1685.

[61] G. Kear, H. Wú, M.S. Jones, F.C. Walsh, Direct-Current Methods for the Estimation of Corrosion Rates in Aqueous Timber Preservatives, Australian Journal of Chemistry, 61 (2008) 455-465.

[62] G. Kear, H.-Z. Wu, M.S. Jones, F. Walsh, Impedance spectroscopy studies of the dissolution of ferrous- and zinc-based materials in aqueous timber preservatives, Journal of Applied Electrochemistry, 38 (2008) 1599-1607.

[63] Anon, AWPA E-17: Standard Method for Determining Corrosion Rates of Metals in Contact with Treating Solutions, American Wood Protection Association, Selma, AL, 2013. 
[64] S.L. Zelinka, Uncertainties in corrosion rate measurements of fasteners exposed to treated wood at $100 \%$ relative humidity, ASTM Journal of Testing and Evaluation, 35 (2007) 106-109.

[65] Anon, Preservative treated wood. Simpson Strong-Tie Technical Bulletin No. TPTWOOD08-R, Simpson Strong Tie, Pleasanton, CA, 2008.

[66] Anon., Copper Naphthenate Corrosivity Data. Retrieved from http://www.anthonyforest.com/pdfs/cunap_corrosivity.pdf on April 1,2013, Anthony Forest Products n.d.

[67] M.A. Freeman, C.R. McIntyre, A comprehensive review of copper-based wood preservatives with a focus on new micronized or dispersed copper systems, Forest Products Journal, 58 (2008) 6-27.

[68] S.L. Zelinka, D.R. Rammer, Modeling the effect of nail corrosion on the lateral strength of joints Forest Products Journal, 62 (2012) 160-166.

[69] K.W. Johansen, Theory of timber connections, International Association of Bridge and Structural Engineering, Bern, Switzerland, 1949.

[70] C. Clausen, S.V. Glass, Build Green: Wood Can Last for Centuries, Forest Service, Forest Products Laboratory, General Technical Report, FPL-GTR-215, Madison, WI, 2012.

[71] K.B. Tator, Introduction to Coatings and Linings, in: S.D. Cramer, B.S. Covino (Eds.), ASM International, Materials Park, OH, 2003, pp. 814-816.

[72] S.L. Zelinka, L. Ortiz-Candelaria, Electrochemical impedance spectroscopy (EIS) as a tool for measuring corrosion of polymer-coated fasteners used in treated wood, Forest Products Journal, 59 (2009) 77-82.

[73] J. Wilson, Aluminum sign corrosion investigation. Final Report \#WI-06-04 WisDOT Highway Research Study \#WI-04-02, Wisconsin Department of Transportation Madison, WI, 2004. 